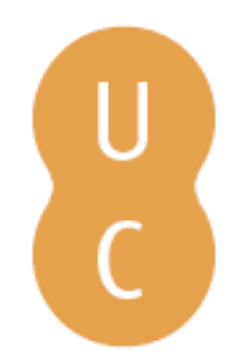

\title{
nombalina
}

\section{A Geração de 70 e o republicanismo: a intervenção polémica de Eça de Queirós}

\author{
Autor(es): $\quad$ Peixinho, Ana Teresa
}

Publicado por: Imprensa da Universidade de Coimbra

URL

persistente: URI:http://hdl.handle.net/10316.2/35873

DOI: $\quad$ DOI:http://dx.doi.org/10.14195/978-989-26-0862-4_6

Accessed : $\quad$ 26-Apr-2023 14:48:08

A navegação consulta e descarregamento dos títulos inseridos nas Bibliotecas Digitais UC Digitalis, UC Pombalina e UC Impactum, pressupõem a aceitação plena e sem reservas dos Termos e Condições de Uso destas Bibliotecas Digitais, disponíveis em https://digitalis.uc.pt/pt-pt/termos.

Conforme exposto nos referidos Termos e Condições de Uso, o descarregamento de títulos de acesso restrito requer uma licença válida de autorização devendo o utilizador aceder ao(s) documento(s) a partir de um endereço de IP da instituição detentora da supramencionada licença.

Ao utilizador é apenas permitido o descarregamento para uso pessoal, pelo que o emprego do(s) título(s) descarregado(s) para outro fim, designadamente comercial, carece de autorização do respetivo autor ou editor da obra.

Na medida em que todas as obras da UC Digitalis se encontram protegidas pelo Código do Direito de Autor e Direitos Conexos e demais legislação aplicável, toda a cópia, parcial ou total, deste documento, nos casos em que é legalmente admitida, deverá conter ou fazer-se acompanhar por este aviso.

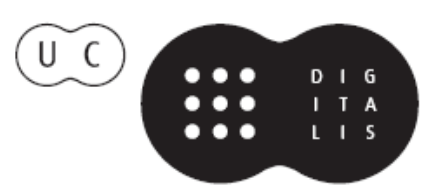




\title{
A EXPERIÊNCIA DA PRIMEIRA REPÚBLICA NO BRASIL E EM PORTUGAL
}

\author{
ALDA MOURÃO \\ ANGELA DE CASTRO GOMES
}

COORDENAÇÃO 


\section{CAPÍTULO 6}

\section{A Geraçáo de 70 e o republicanismo: \\ a intervenção polémica de Eça de Queirós}

Ana Teresa Peixinho

Em países cultos e com uma noção definida de liberdade, república e monarquia constitucionais são tabuletas anunciando uma só mercadoria.

Fialho de Almeida

\section{Objetivos}

PENSAR A PRIMEIRA REPÚbLICA E O MOMENTO DA SUA IMPLANTAÇÃO EM Portugal exige que façamos um exercício retrospetivo que permita perceber de que forma deram entrada os ideais republicanos no nosso país, como germinaram e cresceram num contexto histórico e político complexo, pleno de contradiçóes. Como comenta Romero de Magalhães, logo na abertura da sua recente obra Vem aí a República!: "1910 é o ponto de chegada de uma longa evolução, da falência de uma tateante política monárquica, incapaz de se opor à expansão da ideia de República como salvadora e redentora dos males da pátria” (Magalhães, 2009:17).

Considerar a Implantação da República, cujo centenário este ano se comemora, como um ponto de chegada de um longo período de gestação conduz- 
-nos inevitavelmente até ao início da segunda metade do século XIX, em que uma elite de homens de letras foi progressivamente amadurecendo um conjunto de ideais, importados da Europa, que configuraram um espaço público oitocentista, pleno de antagonismos e que será responsável pela história próxima do país.

A Geração de 70, para muitos uma "geração de ouro", formou-se sobre uma matriz ideológica socialista e republicana, não sendo um acaso Teófilo Braga um dos seus membros e então futuro presidente da República. ${ }^{1}$ Veremos como esta duplicidade ideológica espelhou os posicionamentos de cada um dos elementos desta Geração, todos muito diferentes uns dos outros, mas portadores de um legado cultural e experiencial comum. É conhecida a tese que adota certo ceticismo relativamente ao epíteto de geração para este conjunto de homens, precisamente porque cada um deles absorveu a seu modo bem específico os ideais, os valores e as leituras do tempo. Num artigo dedicado a esta problemática, Filipe Alves Moreira defende e demonstra com textos da época a autoconsciencializaçáo geracional deste grupo, sublinhando naturalmente a complexidade do grupo e a sua heterogeneidade:

Passada a batalha, fica lançado o processo de constituição de uma nova geração nas letras e na sociedade portuguesa, processo que não passará sem que os seus membros reflitam sobre a comunidade de interesses, estéticas, ideologias e objetivos que os une — ou não. (Moreira, s/d:4)

Assumimos, aqui, esta visão do problema, considerando com João Medina, Álvaro Manuel Machado e outros a propriedade do termo geração para significar o núcleo da elite intelectual da segunda metade do século XIX. Tentaremos perceber de que forma o substrato ideológico republicano penetrou na constituição desta geração e de que modos diversos cada um dos seus membros o absorveu. O caso de Eça de Queirós pareceu-nos paradigmático: embora a prematura morte não lhe tenha permitido assistir à implantação da República em Portugal, deixou-nos inúmeros textos em que assume posicionamentos

\footnotetext{
${ }^{1}$ Teófilo Braga, um dos signatários das Conferências do Casino, preside o primeiro Governo Provisório da Primeira República Portuguesa, criado logo após o golpe de Estado de 1910. Posteriormente, substitui Manuel de Arriaga, primeiro presidente eleito, quando este teve de resignar após a Revolta de 14 de Maio de 1915.
} 
sobre as vantagens e desvantagens do novo regime, tanto em Portugal como no Brasil. Sobre esses textos nos debruçaremos, de forma a tentar captar as malhas da complexidade do movimento republicano, antes da sua consolidação em Portugal, em 1910.

Estamos conscientes de que as opiniốes de Eça não são, de forma alguma, tão marcadamente ideologizadas nem politizadas como as de um Antero ou de um Oliveira Martins. Eça foi, acima de tudo, um artista, um escritor, um esteta. Bastará recordar que a sua intervenção nas Conferências do Casino em 1871 foi precisamente sobre o Realismo e a Arte. No entanto, acreditamos que, por isso mesmo, as posiçóes queirosianas, patentes de forma dispersa em vários textos, representam de um modo mais vívido a forma antagónica e complexa como sua Geração se apropriou dos ideais republicanos, reinterpretando-os em função de um projeto para o país. Além do mais, o facto de Eça ter vivido a maior parte do seu tempo fora de Portugal, convivendo de perto com realidades políticas e sociais mais evoluídas do que a nossa, lhe permitiu assumir-se como uma voz e um olhar distanciado, mais lúcido, que de um modo mais completo pôde perceber o que estava em causa. A experiência como cônsul em Paris e o contacto indireto com o Brasil — através da assídua colaboração com a Gazeta de Notícias do Rio de Janeiro - proporcionou ao escritor uma leitura mais abrangente dos cenários políticos.

Embora não seja historiadora, não tendo por isso a pretensão de me aventurar numa abordagem histórica, acredito que o discurso da história também se pode fazer com contributos outros, provenientes de áreas diversificadas.

\section{A utopia como marca geracional}

Numa conhecida carta de feição claramente memorialista endereçada a Carlos Mayer, publicada na Gazeta de Portugal em 1867, Eça de Queirós revive intensamente o ambiente coimbrão que assistiu à famosa querela da Questão Coimbrâ. O seu destinatário explícito, Carlos Mayer, um membro da geração do autor, seu colega em Coimbra que, no final do século, integrará o grupo dos 11 "Vencidos da Vida”, é das figuras menos projetadas desta geração, mas é de facto a personalidade escolhida por Eça de Queirós para destinatário. 
Parece-nos incontestável ler esta carta pública como um marco decisivo nos posicionamentos doutrinários de Eça de Queirós, quer pelo facto de ser um texto inaugural dentro do género, quer ainda por ser o único documento escrito pelo autor sobre a primeira fase da sua vida literária, de matriz romântica, como se sabe. Trata-se, portanto, de um exercício retrospetivo com uma importante dimensão doutrinária, através do qual Eça evoca a atmosfera romântica em que germina a geração coimbrã: diz, a dado momento, "na arte só têm importância os que criam almas e não os que reproduzem costumes" (Queirós, 2009:93). Esta afirmação encontra-se nos antípodas daquilo que, poucos anos mais tarde, Eça afirmará na sua conferência de 1871, na qual se baterá pelo empenhamento social do escritor e pela sua submissão à verdade, na defesa do realismo.

Nesta carta, a assunção do romantismo passa por uma noção muito clara de sua partilha geracional, facto que se projeta na escolha do destinatário explícito da carta, um companheiro próximo de Eça, que com ele partilhou a vida de boémia cultural coimbrã. A dado momento, o escritor afirma:

Nós, meu amigo, somos uma geração desiludida por três revoluçôes, amolecida por uma invenção horrível - a música, tomada da dúvida religiosa, geração que vê esvaecer-se Cristo - a quem tanto tempo amou, e não vê chegar a liberdade por quem há tanto tempo espera (Queirós, 2009:92).

Uns anos mais tarde, em 1878, numa outra carta pública publicada n' $A$ Renascença e dirigida ao seu diretor Joaquim de Araújo, Eça, ao traçar o panegírico de Ramalho Ortigão, afirma o seguinte:

Há quase doze anos apareceu, vinda parte de Coimbra, parte daqui, parte de acolá, uma extraordinária geraçáo: educada já fora do catolicismo e do romantismo, ou tendo-se emancipado deles, reclamando-se exclusivamente da Revolução e para a Revoluçáo. Que tem feito ela? [...] Esta geração tem o aspecto de ter falhado (Queirós, 2009:113).

Já no final do século, em 1896, Eça escreve um excelente texto para o In Memoriam de Antero, a que deu o título "Um génio que era um santo", onde evoca a figura tutelar de Antero, os tempos de Coimbra, o Cenáculo lisboeta: 
E do Cenáculo, donde, antes da vinda de Antero (que foi como a vinda do rei Artur à confusa terra de Gales), nada poderia ter nascido além de chalaça, versos satânicos, noitadas curtidas a vinho de Torres, e farrapos de filosofia fácil, nasceram, mirable dictu, as Conferências do Casino, aurora de um mundo novo, mundo puro e novo que depois, ó dor, creio que envelheceu e apodreceu... (Queirós, s/d.:268-269).

Estes três textos, escritos em fases bem distintas da vida de Eça de Queirós, apontam para algumas linhas importantes que nos permitem configurar a Geração de 70 como geração em permanente busca e em sistemática autorrevisão. Senão, vejamos como todos eles aludem, antes de mais, a um sentido geracional muito claro. Se é certo que, como comenta Álvaro Manuel Machado, dificilmente se poderá estabelecer um paralelo entre as vidas dos membros desta geração, todos eles de origens socioculturais diversificadas, com interesses culturais diferentes e orientaçóes políticas diversas, também não é menos verdade que "houve essa convergência momentânea, esse ponto de encontro histórico decisivo, esse súbito partilhar de ideias" (Machado, 1998:31) que nos permite falar em sentimento geracional, projetado nas palavras de Eça, em diferentes tempos.

Também nos parece sobressair destas cartas queirosianas o denominador comum que unia estes homens: a revolução, entendendo-se esta como uma enorme ânsia de mudar e de inovar, procurando um novo sentido para os destinos pátrios. Perante um Portugal estagnado, dominado por uma medíocre burguesia capitalista, provinciano e fechado sobre si mesmo, vivendo da baixa imitação dos grandes centros urbanos europeus, contaminado por um imperialismo inglês, desde o início do século, esta Geração queria um país diferente, que miraculosamente fosse atingido por uma revolução a todos os níveis, aderindo ao verdadeiro progresso e não se limitando a um mero e aparente progresso material de que Fontes Pereira de Melo fora o grande responsável. Finalmente, todos os textos traduzem a desilusão e o falhanço, projetado como sabemos no célebre grupo "jantante" dos Vencidos da Vida, metáfora do idealismo cético que caracterizou a Geração de 70. Como explica Álvaro Manuel Machado "idealizavam ao mesmo tempo um Portugal que, de facto, nem existia na época em que viveram [...] nem talvez tenha existido nunca" (Machado, 1998:11). 
Ilustração 1

Os onze Vencidos da Vida

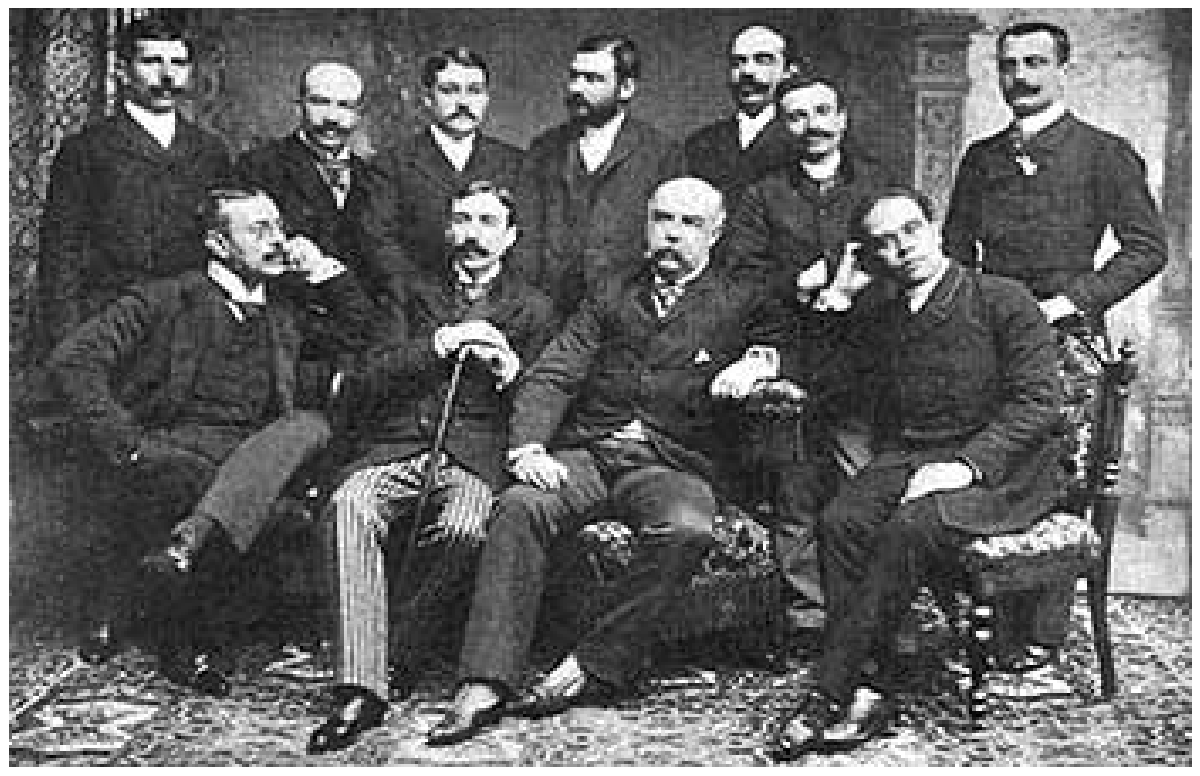

De pé: Conde de Sabugosa, Carlos Mayer, Carlos Lobo de Ávila, Oliveira Martins, marquês de Soveral, Guerra Junqueiro e conde de Arnoso; sentados: Ramalho Ortigão, Eça de Queirós, conde de Ficalho e António Cândido.

De facto, se analisarmos os perfis dos membros desta geração, as suas intervençóes públicas, percebemos que a utopia e o sentido do tempo foram marcas indeléveis do seu empenhamento no espaço público. Utopia patente numa vontade de "aceleração da história"; sentido do tempo projetado no modo como lidaram com essa mesma história. Será precisamente este inconformismo que ditará a transformação desta geração, num grupo de vencidos, num final de século marcado pelo desencanto e pela frustração. Os Vencidos da Vida, como é do conhecimento geral, são um grupo de 11 homens, entre eles alguns bem conhecidos da vida cultural portuguesa, como Guerra Junqueiro, Carlos Mayer, Ramalho Ortigão, Oliveira Martins e, naturalmente, Eça de Queirós, que durante dois anos organizavam umas reuniôes “jantantes” onde confraternizavam e, naturalmente, discutiam assuntos vários. Eça de Queirós publicou no jornal O Tempo, a 29 de Março de 1889, um texto que visava explicar, com muita ironia e algum humor, que grupo era esse que tanta publicidade gerava na imprensa: 
O que de resto parece irritar o nosso caro CORREIO DA MANHÃ é que se chamem vencidos àqueles que para todos os efeitos públicos parecem ser realmente vencedores. Mas que o querido órgão, nosso colega, reflicta que para um homem, o ser vencido ou derrotado na vida depende, não da realidade aparente a que chegou — mas do ideal íntimo a que aspirava (Queirós, 2006:34).

Será este ideal íntimo, bem vívido ainda na década de 1870 , que constitui o elo destes homens.

\section{O embrionário movimento republicano}

Em Maio de 1871, estamos nas vésperas da realização das Conferências do Casino que, como é do conhecimento geral, constituem um marco de afirmação importantíssimo para a Geração de 70; também é o tempo que antecede a publicação de As farpas de Eça e Ramalho, com os seus propósitos reformistas e satíricos. Trata-se de um período conturbado, tanto em nível nacional como internacional, em que, finalmente, a geração germinada em Coimbra, que disputara a célebre Questão Coimbrã e que se juntara no Cenáculo lisboeta, vem a público afirmar os seus propósitos e as suas exigências. Digamos que as Conferências Democráticas se constituem como o primeiro momento público simbólico de consolidação identitária deste grupo, para mais num momento particularmente sensível da conjuntura internacional: não esqueçamos que a Comuna de Paris foi "proclamada [...] em 18 de Março de 1871 e ainda se combatia nesta cidade quando em 29 de Abril apareceu o primeiro anúncio na Revolução de Setembro dizendo que num dos salóes públicos de Lisboa se iam efetuar conferências políticas e sociais" (Saraiva, 1995:42).

De facto, as Conferências do Casino, cujo programa é divulgado em Maio de 1871 e subscrito por Antero, Adolfo Coelho, Augusto Soromenho, Eça, Germano Meireles, Teófilo Braga, Oliveira Martins, entre outros, constituem um importante marco para a história ideológica e cultural da segunda metade do século XIX, sendo o produto heterogéneo e livre de um grupo de jovens 
que lutava contra o cinzentismo, a indiferença, a apatia e o desfasamento do país em relação à Europa. Como explica Carlos Reis (1990:46), as linhas orientadoras da Geraçáo de 70 "nem sempre convergentes ou harmoniosamente congraçadas, tentam ser alternativas para a apatia ideológico-social em que estagnara a Regeneração, apatia que será, por espírito de rebeldia e ânsia de renovação, uma das grandes motivaçóes das Conferências”.

Se percorrermos o pequeno texto programa das Conferências Democráticas, captamos precisamente essa forte vontade de mudança, de abanar consciências, de dinamizar um debate público que se centrasse na urgente integraçáo de Portugal na Europa do seu tempo:

Abrir uma tribuna, onde tenham voz as ideias e os trabalhos que caracterizam este momento do século, preocupando-nos sobretudo com a transformaçáo social, moral e política dos povos;

Ligar Portugal com o movimento moderno, fazendo-o assim nutrir-se dos elementos vitais de que vive a humanidade civilizada. (apud Machado, 1998:114)

É sabido que o substrato ideológico socialista das Conferências tem profundas relaçôes com o movimento republicano, em germinação desde há algumas décadas e que se solidifica com a criação do Partido Republicano, na década de 1870, impulsionado também pela proclamação da República em Espanha, em 1873. João Medina considera que o republicanismo funciona como "uma espécie de duplo ou de gémeo uterino" do socialismo, assumido por todos os jovens conferencistas. Aliás, o autor realça o facto de Bordalo Pinheiro, na caricatura das Conferências publicada n'A Berlinda, ${ }^{2}$ representar

\footnotetext{
${ }^{2}$ A Berlinda foi uma publicaçáo lançada a 5 de Julho de 1870 por Rafael Bordalo Pinheiro e Alfredo Ribeiro, como "reproduçóes d'um álbum humorístico ao correr do lápis" (Rafael e Santos, 2001:102). Segundo Guilherme de Oliveira Martins, foi o último número desta folha que a tornou célebre e muito citada, pois tem como tema a proibição das Conferências do Casino: "As Conferências Democráticas proibidas no Largo da Abegoaria são o prato forte. [...] A 5 de Julho, Rafael Bordalo Pinheiro manifesta claríssima simpatia pelo 'espírito das Conferências' e pelos seus protagonistas. O entusiasmo é tal que ele se inclui entre os injustiçados. São 30 imagens ordenadas em cinco planos com legendas do próprio desenhador. Ávila é representado com as penas de pavão e o seu inefável cache-nez. Carlos Bento, o ministro da Fazenda, pede esmola (sempre os efeitos da crise...). Contra a decadência burguesa saem de dentro de um barrete frígio os heróis - 'nós!' - Antero, Eça, Batalha Reis, Soromenho, Saragga e Adolfo Coelho" (Martins, 2005:2).
} 
o grupo dentro de um barrete frígio, "símbolo tão claro da República" (Medina, 1984:16 e segs.).

\section{Ilustração 2}

As Conferências do Casino por Bordalo Pinheiro em A Berlinda, nำ 7

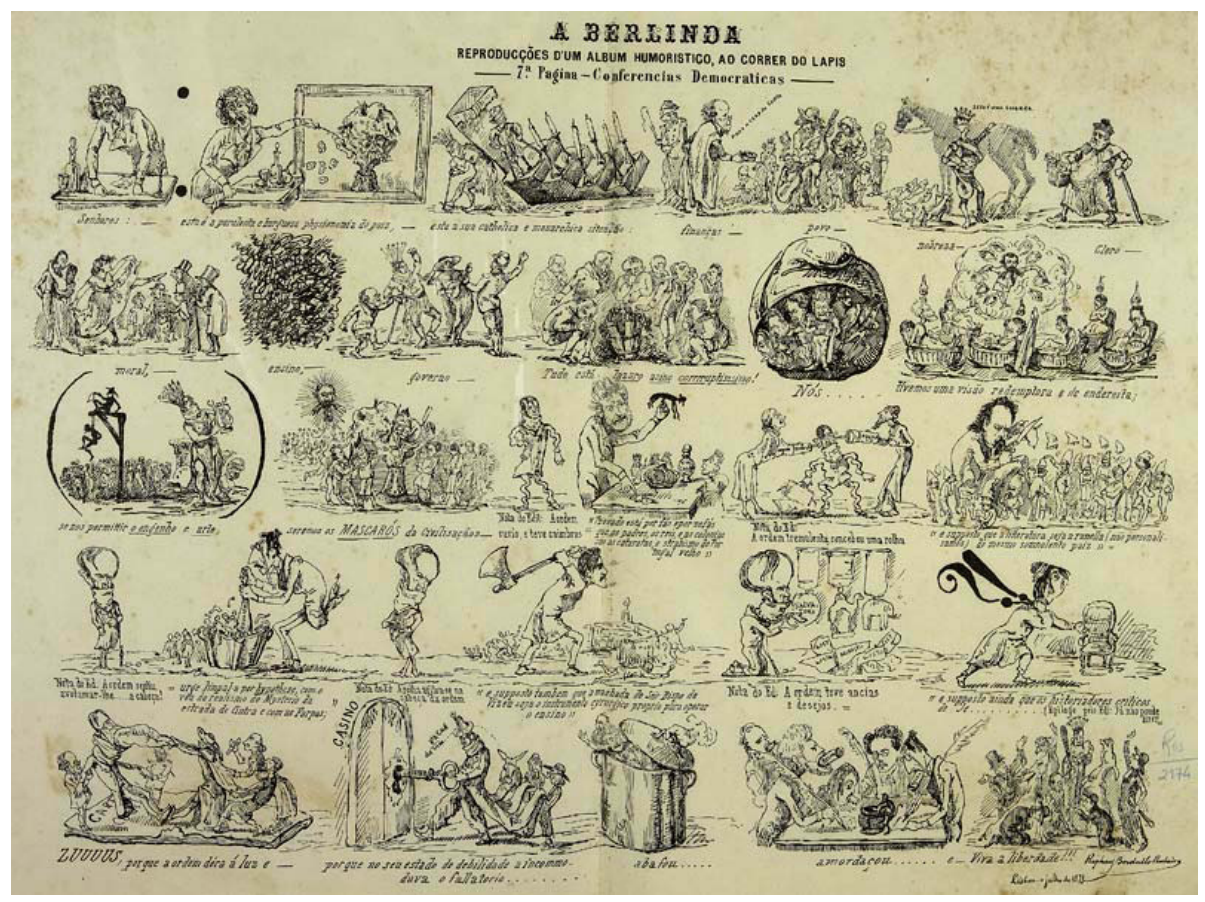

No entanto, a tese defendida por João Medina secundariza a importância desse ideal republicano, em função do fundo socialista proudhoniano de que Antero era o símbolo máximo: "Republicanos são quase todos eles, os moços de 71, mas são sobretudo fiéis ao socialismo, e nesse preciso vetor muitos se hão de afirmar ou reafirmar, mesmo quando, como Fuschini, ingressarem no 
'establishement' da Realeza” (Medina, 1984:17). Além do mais, como explica António José Saraiva, “os jornais conservadores relacionavam as Conferências com os acontecimentos que ameaçavam a ordem na Europa, não só em Paris, mas na Itália e na Espanha" (Saraiva, 1995:44). Quer isto dizer, portanto, que a realização das Conferências bem como a posterior publicação de As farpas eram entendidas como atividades subversivas, que punham em perigo a ordem estabelecida, abrindo o país à entrada de ideias europeias, entre elas o socialismo e o republicanismo. Tanto assim era que as conferências foram encerradas compulsivamente por portaria governamental, o que terá motivado a publicação de inúmeros textos, bastante emotivos e inflamados, divulgados em jornais da época (sobretudo naqueles que acolheram e apoiaram as Conferências, como a Revolução de Setembro, o Jornal do Comércio, o Diário Popular, entre outros) provindos de diferentes conferencistas. ${ }^{3}$

Também Álvaro Manuel Machado afirma que a oposição socialismo/republicanismo é intrínseca à Geração de 70, levando mesmo a uma cisão no seio da própria geração: "por um lado, os socialistas utópicos como Antero, e de certo modo, Eça de Queirós; por outro, os partidários do republicanismo pequeno-burguês, como Teófilo Braga, Guerra Junqueiro e o próprio Ramalho Ortigão [...]” (Machado, 1998:28).

O certo é que, antes dessa cisão e da formação de dois partidos diferentes — o republicano e o socialista — Antero, por exemplo, funda um jornal com Oliveira Martins intitulado $A$ República, ${ }^{4}$ em 1870, em que a ideia de República surge identificada com a de revolução.

Lembremos a importância dos jornais, desde o início do século, na divulgação de ideias políticas e, neste caso específico, na propaganda republicana que se vai insinuando no país, até eclodir no centenário camoniano de 1880 e, posteriormente, na revolta de 31 de Janeiro de $1891 .{ }^{5}$ Lembramos a impor-

\footnotetext{
${ }^{3}$ Muitos desses textos assumiram a forma epistolar e constituem-se como cartas abertas, nomeadamente a carta de Oliveira Martins a Antero e Batalha Reis, de 13 de Julho, publicada no Diário Popular; a célebre carta de Antero ao marquês de Ávila, onde expressamente o signatário comenta "dirigindo-me a V. Ex.ạ, dirijo-me sobretudo ao público: por isso escrevo pela imprensa [...]" (Quental apud Reis, 1990:71); as cartas de Batalha Reis e Adolfo Coelho ao marquês de Ávila etc. (A este respeito, veja-se Medina, 1984:317).

${ }^{4}$ Este jornal teve uma curta duração, o que aliás era comum na época, pois resumiu-se a sete números. Surge em Maio de 1870 e tem como subtítulo "jornal da democracia portuguesa”.

5 "A revolta militar do Porto do dia 31 de Janeiro de 1891 entrou na história do Partido Republicano
} 
tância de um jornal como $O$ Século, ${ }^{6}$ um jornal diário matutino de Lisboa, da responsabilidade de Sebastiấo de Magalhães Lima, membro da Geração de 70 e republicano convicto.

Outra figura importante na construção de uma filosofia republicana foi Joaquim Pedro de Oliveira Martins (1845-1894). Também para este historiador e ideólogo, a república, mais do que um regime político em que o rei era substituído por um presidente, pressupunha uma ideologia e uma visão do mundo específica, no sentido clássico do republicanismo, que teve, como sabemos, um enorme impacto nas revoluçóes setecentistas, tanto na americana de 1776 como na francesa de 1789. Mais do que um partido ou fação, Oliveira Martins defendia a república como ética. Uma ética que, segundo Rui Ramos, assentava em três princípios basilares: a coesão dos membros de uma sociedade como fator indispensável para a sua força; o governo como representante e defesa da comunidade; finalmente, o princípio de sobreposição da autonomia coletiva sobre a individual (Ramos, 1998:170).

Quer isto dizer que, ao falarmos de republicanismo tanto em Antero quanto em Oliveira Martins, devemos ter em atenção a oscilação conceptual de República. Aliás, cremos que a distinção entre republicanismo, como ideologia do Partido Republicano, e republicanismo, como forma de pensar a política e de repensar o país, é fundamental para entendermos os posicionamentos dos membros desta geração. Como explica Rui Ramos (1998:172) no seu artigo, "Oliveira Martins nunca concebeu a 'república' como o governo de um partido republicano. A 'república' era o modelo de uma sociedade funcional e saudável”.

Entendem-se melhor, deste modo, alguns posicionamentos públicos de uma figura como Eça de Queirós. Numa carta ao diretor do Jornal do Comércio, de 4 de Maio de 1871, Eça responde a uma notícia, saída a 2 de Maio, que o dava como fundador de um clube republicano na rua da Prata, negando, com veemência, qualquer envolvimento nessa atividade:

Rogo a V. tome nota desta negativa enérgica, que eu faço todavia sem pavor constitucional, e unicamente para estabelecer a verdade: pelo mesmo motivo, se V.

Português como sua mais importante ousadia antes do 5 de Outubro de 1910" (Mattoso, 1994:187). ${ }^{6} \mathrm{O}$ Século surge a 4 de Janeiro de 1881 e só termina já nos meados do século XX, na década de 1980 . 
noticiasse que eu ia fundar uma camisaria protestaria igualmente porque não é verdade. (Queirós, 2009:97)

Nesse mesmo dia, numa outra carta dirigida ao diretor do Diário Popular, Eça, em conjunto com Ramalho, subscreve uma carta de protesto em relaçáo a um boato que se "espalhava", dando como republicanas As farpas. Estes protestos constituem, não apenas uma reação textual a notícias cujo grau de verdade é posto em causa, mas sobretudo uma tentativa de marcar um distanciamento e uma reserva em relação ao movimento republicano.

Naturalmente que estas "falsas" notícias não surgem por acaso, nem é coincidência o facto de serem contemporâneas da publicação de As farpas ou da realização das Conferências do Casino. Estas intervençóes públicas de Eça, muito pontuais e circunstanciadas, resultam de uma vontade de negar categoricamente o seu envolvimento em factos de cariz político que lhe são injustamente imputados. Factos que ocorrem em momentos particularmente sensíveis, quer do ponto de vista histórico-cultural, quer do ponto de vista da vida do próprio escritor. Relativamente ao boato que dava As farpas como publicação republicana, a que Eça faz referência na carta enviada ao diretor do Diário Popular, ele teria algum fundamento se ocorresse uns anos mais tarde, com $A s$ farpas de Ramalho, em que, segundo Álvaro Manuel Machado, o autor, "tornado discípulo do futuro presidente da Primeira República portuguesa, Teófilo Braga", já revela: o anticlericalismo, os ataques à decadência do regime monárquico e a insistência no tema do colonialismo, evidentes manifestaçóes do "republicanismo pequeno-burguês de Ramalho" (Machado, 1998:32-38). Deste modo, é de crer que Eça se tivesse sentido atingido ao perceber que um projeto reformista e pedagógico como As farpas adquirira o rótulo redutor de republicano, ${ }^{7}$ adjetivo cada vez mais identificado com um partido ou fação e não com uma ideologia mais vasta. E não se trata de uma simples questão semântica: parece-nos, na verdade, poder ler nas entrelinhas destas respostas públicas um claro desejo de Eça em distanciar-se com uma possível organização partidária republicana, aspeto que, embora não de um modo muito explícito,

\footnotetext{
${ }^{7}$ Como explica Carlos Reis, este é "um projeto de mais amplo fôlego, projeto em que o tom crítico, sarcástico, por vezes de efeito cómico, acompanha um propósito de índole pedagógica, apontando para a reforma de costumes e mentalidades na política e no ensino, na literatura e no teatro, na vida religiosa e na diplomacia” (Reis, 1990:30).
} 
vem corroborar a tese de que o republicanismo da Geração de 70 só momentaneamente se terá identificado com aquele que viria a afirmar-se no final do século, dando origem à Revolução de 1910, como os textos finisseculares de Eça, afinal, confirmarão.

Mais uma vez cumpre-nos uma ressalva importante: quando nos referimos ao republicanismo desta geração, fazemo-lo por uma questão meramente prática, pois convém ressaltar a heterogeneidade de reaçóes perante o novo movimento político. Se, em Teófilo, o positivismo de Comte o conduz a uma plena afirmação republicana, já em Oliveira Martins, o republicanismo é um ideal utópico, matizado no socialismo proudhoniano.

\section{Eça e a República: contradições}

Embora as posiçóes ideológicas de Eça, neste domínio, permitam algumas especulaçôes, nomeadamente algumas d'As farpas iniciais, basta que percorramos alguns textos da sua obra ficcional e cronística para percebermos o afastamento explicitado em relaçáo ao republicanismo. Como demonstra João Medina, ao percorrer a galeria de personagens romanescas queirosianas representativas dos ideais republicanos, Eça constrói sempre tipos interesseiros e frustrados: "seja como for, é aqui, n’ $A$ Capital, que Eça examina o grupo dos republicanos com maior acuidade e menos complacência, reunindo-os em torno do triste clube da Rua do Príncipe, onde os vemos divididos [...], fúteis, balofos, [...] azedos, nada fraternos, desconfiados [...], palavrosos e cheios de inconfessáveis ambições pessoais" (Medina, 1984:299).

A corroborar esta representação ficcional que, além do mais, é coerente com o modo negativo e caricatural como o romancista representou todos os setores da sociedade portuguesa, encontramos, na sua obra paraliterária, nomeadamente em artigos de imprensa e em crónicas, uma reflexão e uma tomada de posição sobre a República. Um dos textos em que esse posicionamento é mais claro encontra-se publicado na Revista de Portugal, na última década do século. Trata-se de uma crónica assinada por "Um espectador", intitulada "Novos fatores da política portuguesa", ${ }^{8}$ que é integralmente dedicada à análise

\footnotetext{
${ }^{8}$ Este texto foi publicado no volume II, no 4, Abril, 1890, p. 526-541 da Revista de Portugal (Santana,
} 
do republicanismo em Portugal e do seu peso no contexto problemático do final do século. Neste texto, embora Eça de Queirós jogue com algumas estratégias de distanciamento, a começar pela ambígua escolha do pseudónimo com que o subscreve, é clara a atitude de desconfiança em relação ao movimento republicano como novo sistema político e ideológico que servisse à regeneraçáo do país. Em primeiro lugar, Eça considera que a República representa, no contexto de crise e de decadência da última década do século, um último reduto, mais do que uma estratégia ideológica segura:

De sorte que se vai para a república ou se tende para ela, não por doutrinarismo, por urgência de mais liberdade e de instituiçôes mais democráticas, mas porque numa já considerável parte do País se vai cada dia radicando mais este desejo: antes qualquer coisa do que o que está! (Queirós, 1995:86).

Considerando mesmo a revolução republicana um perigo para a autonomia, a estabilidade e a uniáo nacionais, num tom catastrofista, na segunda parte do seu artigo vaticina que "a república não pode deixar de inquietar o espírito de todos os patriotas. Ela seria confusão, a anarquia, a bancarrota" (Queirós, 1995:93).

Esta visão da República e dos republicanos, apesar de ter sido escrita duas décadas mais tarde do que as cartas públicas acima referidas, revela pelo menos da parte de Eça uma postura antirrepublicana muito clara. Quer pela sua juventude, quer ainda pelo carácter embrionário do republicanismo no ano de 1871, as palavras que o autor deixa nas suas cartas de indignação não são tão duras, nem tấo contundentes, até porque não perseguem os mesmos objetivos analíticos do texto da década de 1990, mais a mais uma década em que se reacende no país a propaganda republicana, em parte devido ao Ultimatum inglês.

1995:38) e a identificação de sua autoria foi revelada, em 1975, por Ernesto Guerra da Cal: "este artículo, en el que se hace la historia del republicanismo en Portugal, habia sido hasta ahora atribuido a Oliveira Martins [...] La razón de esta falsa atribución es fácilmente explicable: Eça lo firmo com el pseudónimo 'Um espectador' y como Oliveira Martins usaba el de 'Spectator' en la própria Revista de Portugal, la identificación de ambos era natural. Sin embargo, recientemente se ha revelado la existencia de un original autógrafo compuesto de una serie de hojas de papel de $31 \times 30 \mathrm{cms}$., escritas por un solo lado, con un amplio margen a la izquierda, e inequívocamente salidas de la pluma de Eça" (Guerra da Cal, 1975:248). O texto encontra-se, presentemente, publicado em: Queirós (1995:83-95). 
Se dúvidas houvesse quanto ao posicionamento de Eça em face da República e dos republicanos no final de século, bastará chamarmos à colação uma carta privada, dirigida a Oliveira Martins e datada de Paris, 5 de Fevereiro de 1891, em que o escritor se refere em termos contundentes à Revolução de 31 de Janeiro desse ano, no Porto: "Telegrafei-te, perguntando se querias, ou podias, fazer o artigo que a Revista não pode deixar de publicar sobre esse furúnculo revolucionário que rebentou no Porto, como sintoma de doença geral” (Queirós, 1983:153).

É este o início da missiva em que Eça de Queirós convida Oliveira Martins a escrever um artigo para a Revista de Portugal sobre essa primeira revolução republicana, que qualifica metaforicamente de "furúnculo revolucionário". Justifica-se em seguida por não poder ser ele próprio a produzir o dito artigo, alegando a distância que o separa do palco dos acontecimentos "alumiado apenas pela lanterna mortiça da Agência Havas”. Apesar de tudo, confirma a opinião geral que em Paris é veiculada sobre essa tentativa frustrada de mudança de regime:

Esse é o começo da débâcle [...] é natural que o caso do Porto seja um lever de rideau, e que o partido republicano, que, em Lisboa e nas cidades da província, permanece intacto e imperturbado, sem ter perdido nem um homem, nem um ceitil, nem uma ilusão, prepare para breve o drama a sério. (Queirós, 1983:154)

Se, no texto da Revista de Portugal, a que atrás fizemos referência, a análise do republicanismo é subscrita por um pseudónimo, aqui, num ato de comunicação privada, Eça declara com firmeza a sua relutância relativamente à República e ao partido republicano. É interessante verificarmos que, em termos de afirmação pública, a contundência das suas críticas é camuflada sobre outro nome, outra assinatura, mas, no domínio privado, essas críticas e posicionamentos aparecem claramente assumidos. Esta atitude pode ter diversas leituras. Estaria Eça a adiar uma afirmação pública das suas ideias relativas ao novo regime por não ter a certeza absoluta das suas convicçóes? Desejaria manter-se numa atitude de certo distanciamento, favorecido aliás pela distância geográfica, relativamente ao que se passava no país? Ou, por outro lado, temeria afirmar as suas ideias, convicto de que a monarquia agonizava sem retorno? O certo é que as palavras de Eça eram certeiras: o "drama a sério" estaria para 
breve, embora a sua prematura morte não lhe tenha permitido testemunhar o acontecimento.

Na década de 1890, a ausência prolongada do país também é um fator decisivo no modo como o autor perspetiva os acontecimentos. $\mathrm{O}$ seu contacto direto com a realidade política francesa - uma república bem mais antiga do que a nossa - proporcionou ao escritor um olhar comparativo e mais esclarecido sobre o que estava em causa. Este confronto entre a realidade portuguesa e a europeia está sobretudo patente nas crónicas da última década do século que o escritor enviava regularmente de Paris para a Gazeta de Notícias do Rio de Janeiro. O que estas cartas parisienses vêm comprovar é um alargamento dessa crítica aos políticos europeus, mesmo àqueles dos países civilizados que já tinham adotado o regime republicano, como era o caso da França. Os republicanos franceses eram, na opiniáo do cronista, incapazes de transmitir ao povo uma imagem de solidez e uma definição de objetivos, preferindo estabelecer ligaçóes com governos totalitários, como a aliança franco-russa ilustra. Até mesmo os valores da Revolução Francesa se encontram lamentavelmente perdidos e esbatidos. Em 1896, numa das Cartas familiares de Paris, Eça de Queirós publica "A propósito de Thermidor". Partindo de um facto da atualidade - a encenação da peça Thermidor de Victorien Sardou —, que cinco anos antes havia sido censurada por pôr em causa a República e a liberdade, Eça alarga-se numa série de consideraçóes sobre o impacto da mensagem da Revoluçáo Francesa no final do século, sendo desta vez mais contundente nas críticas e mais demorado na análise. A reabilitação desta peça, para mais enriquecida com "episódios inéditos e todos desagradáveis para a Revolução", significa, segundo Eça, o progressivo esquecimento em que vinha caindo a mensagem revolucionária: "Porque (ai de nós!) uma grande indiferença, à maneira da sombra dum crepúsculo, começa a descer sobre a Revolução Francesa" (Queirós, 2002:609).

Este esquecimento é tanto mais doloroso para o cronista quanto ele contrasta com o entusiasmo com que, nos tempos universitários de Coimbra, ele próprio e a sua geração vivificavam a Revolução e os seus homens:

De Marat, de Camilo Desmoulins, de Saint-Just, de todos os homens da Revolução nunca dizíamos “era”, mas "é”, no presente do verbo, porque para nós eles estavam presentes, sempre vivos, habitando Paris, habitando também Coimbra, 
vivos e presentes em todo o lugar onde houvesse um coração revolucionário para os compreender. (Queirós, 2002:610)

O cronista não se restringe a constatar esse esquecimento, alargando-se numa análise histórica e política, tentando mostrar aos seus leitores os fatores que terão contribuído para o esbatimento da mensagem da Revolução, neste final de século, e é muito claro ao apontar o dedo aos políticos da Terceira República:

A Terceira República não faltou a este dever prudente: - e apenas instalada nos palácios onde habitara o Segundo Império, imediatamente desaparelhou e recolheu a Revolução. A grande época que até aí andava sempre, em pleno sol, no rumor da vida ambiente, misturada ao redemoinhar das ideias e dos interesses, penetrou no silêncio e na sombra dos arquivos e aí ficou, como cousa finda, aposentada, já catalogada. (Queirós, 2002:612)

As opinióes e críticas à política europeia são muitas e bastante interessantes nestes textos escritos para a Gazeta de Notícias, assistindo-se ao aluimento de uma visão ideal — outra utopia — dessa Europa desenvolvida.

No entanto, escrevendo para leitores brasileiros, Eça também abordou alguns temas que eventualmente poderiam encontrar eco na opiniáo pública desse país de além-mar. Não podemos, contudo, deixar de sublinhar, com alguma estranheza, o facto de o correspondente ter silenciado temas táo importantes da atualidade brasileira, como a promulgação da Lei Áurea, em 1888, que promove a abolição da escravatura, ou mesmo a implantação da Repúbli$\mathrm{ca}$, no ano seguinte.

No entanto, em 1889, na Revista de Portugal, na secção "Notas do mês", o escritor publica um texto, assinado com o pseudónimo João Gomes, que o seu filho José Maria viria a integrar em Cartas inéditas de Fradique Mendes, sob o título "A Revolução do Brasil" (Guerra da Cal, 1975:247). Num tom jocoso e humorístico, sem deixar de transmitir uma ideia e uma posição do cronista, o texto desenvolve um extenso comentário à intempestiva revolta brasileira que deu origem ao golpe de estado republicano no Brasil, em 1889. ${ }^{9}$ Embora

\footnotetext{
${ }^{9}$ A Proclamação da República brasileira ocorreu em 15 de novembro de 1889 e pôs fim à soberania do imperador d. Pedro II. Esta revolta foi liderada pelo marechal Deodoro da Fonseca que, na praça da
} 
valesse a pena um estudo exaustivo deste texto, por constrangimentos espaciais, limitamo-nos a chamar a atenção para um interessante comentário de Eça que nos parece ilustrar a forma como o ideal republicano foi assumido neste fim de século pela Geraçáo de 70. Diz a dado momento, comentando a forte penetração do republicanismo na opinião pública brasileira:

O movimento revolucionário, porém, vinha sobretudo dos bacharéis, dos moços das escolas, que ansiavam pela República, não porque o Império lhes fechasse o acesso às carreiras $[\ldots]$ mas para poderem realizar um velho ideal jacobino, já entre nós desacreditado e um pouco obsoleto, e que no Brasil domina ainda as inteligências tropicalmente entusiásticas e crédulas. Os melhores espíritos brasileiros ainda admiram Pelletan ${ }^{10}$ - que, em S. Paulo e no Rio, se lê desesperadamente. (Queirós, 1979:938)

Além disso, neste final de século, o escritor tinha já conquistado uma posição no mundo das letras que lhe permitia gozar de amplas liberdades: Eça era quase um "cortesão", amigo próximo do conde de Arnoso, como é sabido, secretário particular do rei. ${ }^{11}$ Atentemos no obituário que escreve sobre d. Luís, publicado na Revista de Portugal. Depois de enaltecer as qualidades do rei morto, termina o seu texto com um elogio ao príncipe d. Carlos, "um príncipe moderno, brilhante, cultivado, requintado, de aptidóes complexas e fortes, de inteligência largamente absorvente, de vida excelentemente pura [...]" (Queirós, 1979:930). Mas vai mais longe afirmando a força e o poder do rei, como baluarte do país num tempo de crises e de incertezas: "Começa este reinado no momento em que, pela dispersa hesitação das inteligências, pelo incurável enfraquecimento das vontades, pela desorganização dos partidos,

Aclamação do Rio de Janeiro, com um grupo de militares do exército, depôs o imperador do Brasil, d. Pedro II, e o presidente do Conselho de Ministros do Império, o visconde de Ouro Preto.

${ }^{10}$ Presidente do Partido Radical Socialista Francês.

${ }^{11}$ Diz-nos António José Saraiva: “O príncipe herdeiro D. Carlos casara em 1886 com a princesa D. Amélia, uma mulher bela, que teve o privilégio de ser admirada e quase cortejada por Eça de Queiroz, o amigo dos últimos anos de Oliveira Martins. Assim se formou uma roda em torno do jovem casal, constituída por gente do gabinete do Príncipe, parte da qual privava com Eça de Queiroz (que se jactava da sua fidalguia), como o marquês de Ficalho, mordomo do Paço, Bernardo Pindela, secretário particular do Príncipe, o conde de Arnoso ou o conde de Sabugosa. Eram cortesãos literatos, sensíveis ao prestígio literário dos antigos promotores das Conferências do Casino" (Saraiva, 1995:137-138). 
pela inércia das classes — o rei surge como a única força que no país ainda vive e opera” (Queirós, 1979:930).

Também a leitura do panegírico da rainha d. Amélia, publicado na Revista Moderna, a 15 de Janeiro de 1898, e publicado em Notas contemporâneas, ilustra bem a proximidade quase bajuladora de Eça de Queirós à corte. Guerra da Cal inclusive informa que a própria rainha felicitou o romancista (Guerra da Cal, 1975:295) pelo texto. Trata-se de um retrato em que enaltece as qualidades da rainha de Portugal: a sua beleza, a sua graça, a sua bondade, a sua cultura, o modo como acolheu o conceito da nova pátria no seu coraçáo etc. Um retrato oficial que, na nossa opinião, aponta claramente para uma aproximação do escritor à corte.

Não se tratando de uma manifestação clara de antirrepublicanismo, este panegírico da rainha d. Amélia náo deixa de insinuar uma atitude que podemos adjetivar de bajuladora, mais característica de um poeta aúlico das cortes ancien régime do que de um escritor que sempre olhou com desconfiança e com saudável distanciamento as instituiçóes e os poderes oficiais. Curiosamente, e cremos que por temer este rótulo, Eça termina o texto afirmando a sua desilusão e ceticismo perante qualquer um dos regimes alternativos neste fim de século:

Depois, a presença angustiosa das misérias humanas, tanto velho sem lar, tanta criancinha sem pão, e a incapacidade ou indiferença de monarquias e repúblicas para realizar a única obra urgente do mundo - "a casa para todos, o pão para todos", lentamente me tem tornado um vago anarquista entristecido, idealizador, humilde, inofensivo... (Queirós, 1986:1615)

Se este retrato dedicado à rainha aponta para um Eça cortesão, próximo da monarquia, estas palavras finais trazem consigo uma nota dissonante que não se coaduna com um panegírico tradicional. Elas são a expressão de um sentido de desistência e desânimo, bem adequado a um vencido da vida, para quem já não há soluções redentoras, nem na Monarquia, nem na República.

\section{Em jeito de conclusão}


"Um pessimista é um homem que diz a verdade prematuramente" é uma expressão do dramaturgo francês Edmond Rostand que traduz, em nossa opinião, o posicionamento desta geração oitocentista que sonhou para além do seu tempo, acabando por morrer encarcerada nele e abatida pelo desalento do presente.

$\mathrm{Na}$ verdade, tratou-se aqui de fazer uma brevíssima incursão pelas relaçóes germinais entre a ideia de República e a Geração de 70. Dissemos, no começo deste texto, que esta geração viveu de forma peculiar o tempo e a história, em permanente litígio com o presente, ansiando por outro Portugal muito além do seu tempo.

Pela incursão que acabámos de fazer por alguns vultos da Geração de 70, sobretudo Eça de Queirós, percebemos que a implantação da República em 1910 percorreu um longo e sinuoso caminho, que se inicia na primeira metade do século XIX e que é acalentado e construído pelas reflexóes e pelos posicionamentos de um conjunto de intelectuais, homens de letras, que marcaram a segunda metade do século.

Parece-nos também que, à vista destes homens, a ideia de República surge inicialmente como uma ideia redentora, capaz de revolucionar o país, levando-o para fora do pântano em que a monarquia constitucional e a Regeneraçáo o mergulharam. Não se tratava de defender os propósitos partidários da República, mas a sua essência ideológica. Como ficou demonstrado anteriormente, tanto Antero quanto Oliveira Martins pugnaram por ideais republicanos, num momento em que acreditavam ainda que era possível regenerar o país, através de valores e princípios éticos do republicanismo clássico. $\mathrm{O}$ texto que Eça publica na Revista de Portugal é disto um claro sintoma. Não se trata de defender o partido ou os partidos republicanos, nem tão pouco acalentar por uma mudança de regime que apenas se traduzisse numa operação de cosmética: tratava-se para estes homens de reedificar o edifício da democracia em pilares sólidos que, sobre as bases já tão esquecidas dos princípios revolucionários franceses, sustentassem o país e o transformassem.

A história finissecular encarregou-se de os transformar num grupo de vencidos. O que os uniu nesse problemático fim de século, afinal, foi o sentimento de frustraçáo e de ceticismo, vivido por cada um à sua maneira, que está bem patente no desabafo humanista de Eça, no final do panegírico da rainha d. Amélia: a inutilidade de qualquer um dos dois regimes em suprir os grandes problemas das sociedades ocidentais. 


\section{Fontes}

A REPÚBLICA. Disponível em: <www.bnportugal.pt/>.

QUEIRÓS, Eça de. A rainha. In: __. Obras de Eça de Queiroz. Porto: Lello \& Irmão - Editores, 1986. v. 2: Notas contemporâneas, p. 1607-1616.

. Cartas públicas. Edição crítica de Ana Teresa Peixinho: Lisboa: INCM, 2009. . Correspondência. Edição de Guilherme Castilho. Lisboa: INCM, 1983. v. II. . Notas contemporâneas. Ediçáo de Helena Cidade Moura. Lisboa: Livros do Brasil, s.d.

. O Manifesto d'Os Vencidos. In: VVAA. Os Vencidos da Vida. 1. ed. Porto: Fronteira do Caos, 2006. p. 33-35.

. Obras de Eça de Queiroz. Porto: Lello \& Irmão - Editores, 1979. v. III.

. Textos de imprensa VI - da Revista de Portugal. Edição crítica de Maria Helena Santana. Lisboa: INCM, 1995.

- Textos de Imprensa IV - da Gazeta de Notícias. Edição crítica de Elza Miné e Neuma Cavalcante. Lisboa: INCM, 2002.

\section{Referências}

GUERRA DA CAL, Ernesto. Lengua y estilo de Eça de Queiroz: apêndice bibliografía queirociana sistemática y anotada e iconografia artística del hombre y la obra. Coimbra: Imprensa da Universidade de Coimbra, 1975. t. $1^{\circ}$.

MACHADO, Álvaro Manuel. A Geração de 70. 4. ed. Lisboa: Presença, 1998.

MAGALHÂES, Joaquim Romero. Vem aí a República! 1906-1910. Coimbra: Almedina, 2009.

MARTINS, Guilherme de Oliveira. Uma berlinda em bolandas. 2005. Disponível em: <www.purl.pt/273/1/guilherme-oliveira-martins.html>.

MATTOSO, José (Dir.). História de Portugal. Lisboa: Círculo de Leitores, 1994. v. VI.

MEDINA, João. As Conferências do Casino e o socialismo em Portugal. Lisboa: D. Quixote, 1984.

MOOG, Vianna. Eça de Queirós e o século XIX. 6. ed. Porto Alegre: Instituto Estadual do Livro/Corag, 2006.

MOREIRA, Filipe. A Geração de 70: notas para a história de um conceito. s.d. Disponível em: <www.uefs.br>. 
RAFAEL, Gina Guedes; SANTOS, Manuela. Jornais e revistas portugueses do séc. XIX. Lisboa: Biblioteca Nacional, 2001. v. I.

RAMOS, Rui. Oliveira Martins e a ética republicana. Penélope, n. 18, 1998. Disponível em: <www.penelope.ics.ul>. Acesso em: 10 abr. 2010.

REIS, Carlos. As Conferências do Casino. Lisboa: Alfa, 1990.

SANTANA, M. Helena. Introdução. In: QUEIRÓS, Eça de. Textos de imprensa VI - da Revista de Portugal. Edição crítica das Obras de Eça de Queirós. Lisboa: INCM, 1995. p. 15-48.

SARAIVA, António José. A tertúlia ocidental. 2. ed. Lisboa: Gradiva, 1995. 